\title{
Lagged response of summer precipitation to insolation forcing on the northeastern Tibetan Plateau during the Holocene
}

\author{
Xiaojian Zhang ${ }^{1} \cdot$ Liya Jin $^{2,3}$ (1) Jie Chen ${ }^{3} \cdot$ Huayu Lu ${ }^{1} \cdot$ Fahu Chen $^{3}$
}

Received: 11 February 2017 / Accepted: 6 June 2017 / Published online: 17 July 2017

(c) The Author(s) 2017. This article is an open access publication

\begin{abstract}
The precipitation changes on the northeastern Tibetan Plateau during the Holocene remain unclear due to discrepancies among different proxy records. We compared proxy records with the results from a transient simulation performed using the Kiel Climate Model forced by orbital variations, to analyse summer precipitation changes in this area during the Holocene (9.5-0 ka BP). The model results suggested increasing amounts of summer precipitation from 9.5 to $\sim 6.2 \mathrm{ka} \mathrm{BP}$ and a persistent decline thereafter, which matched well with pollen records but was inconsistent with ostracod $\delta^{18} \mathrm{O}$ records. The Holocene climatic optimum lagged the Northern Hemisphere summer insolation maximum by $\sim 3.5 \mathrm{ka}$, caused by the interplay between the East Asian summer monsoon (EASM) circulation and the mid-latitude westerlies. The ostracod $\delta^{18} \mathrm{O}$ values reflected the strength of the EASM circulation. A strong EASM circulation increased the transport of water vapour towards the northeastern Tibetan Plateau from the northwestern Pacific. Weakened mid-latitude westerlies increased the incursion of cold air masses into the northeastern Tibetan Plateau. During the early Holocene, relatively strong midlatitude westerlies, resulting from an enhanced Arctic Oscillation, reduced summer precipitation on the northeastern Tibetan Plateau, in spite of a strong insolation-driven
\end{abstract}

Liya Jin

jinly@1zu.edu.cn

1 School of Geographic and Oceanographic Sciences, Nanjing University, Nanjing 210023, China

2 School of Atmospheric Sciences, Chengdu University of Information Technology, Chengdu 610225, China

3 MOE Key Laboratory of Western China's Environmental System, College of Earth and Environmental Sciences, Lanzhou University, Lanzhou 730000, China
EASM circulation. The weakening EASM circulation and the strengthening westerlies together induced the decreasing trend of summer precipitation from the middle to late Holocene. In addition, summer precipitation variations were further modulated by sea-surface temperatures in the northwestern Pacific, through weakening the strength of the EASM.

Keywords Holocene - East Asian summer monsoon . Northeastern Tibetan Plateau · Model-proxy comparison . Orbital forcing

\section{Introduction}

The Asian summer monsoon (ASM) is a complex system that includes the Indian summer monsoon (ISM) and East Asian summer monsoon (EASM) (Wang 2006). ISM precipitation is directly influenced by the intertropical convergence zone, associated with tropical heating and ultimately related to solar radiation (Chao 2000; Fleitmann et al. 2007). However, EASM precipitation is mainly caused by a frontal system, which forms when warm and moist air flows brought by the monsoonal southeasterly winds meet the cold air brought by the westerlies (Ding and Chan 2005; Liu et al. 2014a). Therefore, a better understanding of the interaction between the EASM and mid-latitude westerlies is important to reveal the nature of moisture changes in East Asia. The northeastern Tibetan Plateau (Fig. 1) is ideally located to study the interaction between the EASM and mid-latitude westerlies (Lu et al. 2010; An et al. 2012).

A large number of proxy records, especially those based on multiple sediment cores from Qinghai Lake, have been studied to reveal the characteristics of the changes in moisture on the northeastern Tibetan Plateau during the 


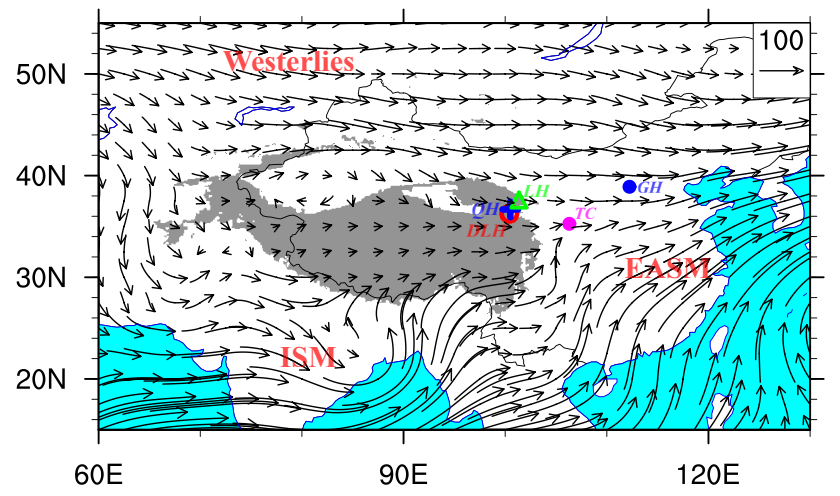

Fig. 1 Mean summer water vapour flux vectors $\left(\mathrm{kg} \mathrm{m}^{-1} \mathrm{~s}^{-1}\right)$, vertically integrated from the surface to $300 \mathrm{hPa}$, during the period 19712000, based on the NCEP-NCAR Reanalysis (Kalnay et al. 1996). Areas above $3000 \mathrm{~m}$ (above sea level) are shaded grey. 'EASM', 'ISM', and 'Westerlies' denote the regions mainly influenced by the East Asian summer monsoon, Indian summer monsoon, and westerlies, respectively. The locations of Dalianhai Lake, Qinghai Lake, Luanhaizi Lake, Tianchi Lake and Gonghai Lake are indicated by the red circle, blue cross, green triangle, magenta dot and blue dot, respectively

Holocene, as well as the history of the ASM. However, significant discrepancies exist among different proxy records; in particular, pollen and ostracod oxygen isotope $\left(\delta^{18} \mathrm{O}\right)$ records indicate different periods for the climatic optimum during the Holocene (Lu et al. 2010; Chen et al. 2016). Pollen records from Qinghai Lake and the surrounding lakes of the northeastern Tibetan Plateau suggest a relatively dry early Holocene, with the wettest period spanning the middle Holocene, and then another dry period in the late Holocene (Shen et al. 2005; Herzschuh et al. 2010; Cheng et al. 2013; Wang et al. 2014a). Pollen-based moisture changes lag the Northern Hemisphere June insolation maxima by $\sim 3 \mathrm{ka}$. A relatively dry climate during the early Holocene is also indicated by the significantly low lake levels of Qinghai Lake during this period (Liu et al. 2013, 2015b; Wang et al. 2014b). However, ostracod $\delta^{18} \mathrm{O}$ records from Qinghai Lake indicate a drying trend in this region throughout the Holocene, closely following Northern Hemisphere summer insolation (Liu et al. 2007; Wang et al. 2011; An et al. 2012). This drying trend is further supported by hydrogen isotope records from Qinghai Lake (Thomas et al. 2016) and Genggahai Lake (Rao et al. 2016).

It is commonly believed that insolation-induced ASM recession dominated the changing trend (Colman et al. 2007; An et al. 2012; Thomas et al. 2016), and that North Atlantic cold events contributed to abrupt declines (e.g., $8.2 \mathrm{ka} \mathrm{BP}$ ) (Ji et al. 2005; Wang et al. 2011; An et al. 2012; Liu et al. 2014b) of precipitation on the northeastern Tibetan Plateau during the Holocene. The northeastern Tibetan Plateau is located in a transitional zone between the EASM and ISM, and it is still not clear which of these monsoon systems (ISM or EASM) controls the precipitation over this area. A number of palynological studies have concluded the EASM to have been the dominant factor influencing precipitation changes during the Holocene (Shen et al. 2005; Liu et al. 2015a; Chen et al. 2016), and the strength of the EASM is believed to have been suppressed by the continental ice sheets during the early Holocene (Chen et al. 2015a, b). Other studies, however, based on stable hydrogen and oxygen isotope records (Liu et al. 2007; Rao et al. 2016; Thomas et al. 2016), suggest that the precipitation over this area has been governed during the Holocene by the ISM.

Considering the considerable controversy outlined above regarding the changes in precipitation on the northeastern Tibetan Plateau during the Holocene, it is of great significance to clarify the situation using some other form of evidence. In this respect, paleoclimate modelling and comparison with proxy records is an extremely effective approach that can be used to understand paleoclimatic changes and their forcing mechanisms. In this study, therefore, we simulated the climate changes over the past $9.5 \mathrm{ka}$ and compared the simulation results with proxy records to explore the changes in moisture on the northeastern Tibetan Plateau during the Holocene and their driving factors.

Below, we introduce the methods used in this research (Sect. 2), including proxy records and climate model simulation. Section 3 compares the simulation results with the proxy records. Section 4 analyses the climatic significance of ostracod $\delta^{18} \mathrm{O}$ in Qinghai Lake, discusses the physical mechanisms responsible for the changes in precipitation on the northeastern Tibetan Plateau during the Holocene, and provides the reason for the mismatch between the simulation and proxy during the late Holocene. The main conclusions are shown in Sect. 5.

\section{Methods}

\subsection{Proxy records}

Most of our knowledge on climatic and environmental changes on the northeastern Tibetan Plateau during the Holocene comes from the sediments of Qinghai Lake (Colman et al. 2007; Chen et al. 2016), which is the largest natural lake in China. The $\delta^{18} \mathrm{O}$ values of ostracod shells and pollen assemblages are widely used as proxies for reconstructing the changes in moisture in this area during the Holocene, as well as the history of the summer monsoon (Shen et al. 2005; An et al. 2012). As a hydrologically closed lake, Qinghai Lake's hydrology is relatively simple, being ultimately controlled by atmospheric precipitation and local evaporation. Most of the precipitation occurs in summer (June-July-August, JJA), which is influenced by 
the ASM (Xu et al. 2007; Thomas et al. 2016). The $\delta^{18} \mathrm{O}$ within ostracod shells inherits the isotopic composition of lake water (Liu et al. 2009), and it has been suggested that Qinghai Lake has a relatively constant hypolimnion temperature of $\sim 6^{\circ} \mathrm{C}$ in summer, owing to the thermal stratification of its waters (Colman et al. 2007). Therefore, the $\delta^{18} \mathrm{O}$ values of the water are independent of temperature and mainly mirror the balance between the amount of precipitation [the $\delta^{18} \mathrm{O}$ values are negatively correlated with the amount of precipitation-the so-called "amount effect" (Dansgaard 1964)] and evaporation in the closed basin (Wei and Gasse 1999; Johnson and Ingram 2004; Colman et al. 2007). Ultimately, the ostracod $\delta^{18} \mathrm{O}$ records from Qinghai Lake can be used to reconstruct the effective humidity of the northeastern Tibetan Plateau. In this study, ostracod $\delta^{18} \mathrm{O}$ records from three sediment cores of Qinghai Lake, with reliable dating control, were employed to compare with the simulation results.

Pollen assemblages directly reflect the vegetation cover associated with certain hydro-thermal conditions (Wang et al. 2014a). Therefore, pollen-based proxies are direct and unambiguous indicators of moisture change (Liu et al. 2015a). Here, a pollen record from a sediment core (QH2000) of Qinghai Lake (Shen et al. 2005) was selected to compare with the ostracod $\delta^{18} \mathrm{O}$ records and simulation results. In addition, there are a number of small lakes spread around the Qinghai Lake region, many of which have been studied in reconstructing the climatic and environmental changes over this area. We used pollen records from two of them-Dalianhai Lake (Cheng et al. 2013) and Luanhaizi Lake (Herzschuh et al. 2010; Wang et al. 2014a).

Finally, we also used a $\mathrm{Mg} / \mathrm{Ca}$-based SST proxy record from core A7 (Sun et al. 2005) in the northwestern Pacific to analyse the possible physical mechanism underlying the variations in precipitation on the northeastern Tibetan Plateau during the Holocene. Two proxy records from Tianchi Lake and Gonghai Lake on the Chinese Loess Plateau were also used to compare with our simulation results. A summary of the abovementioned proxy records is provided in Table 1 . The locations of the proxy records are shown in Fig. 1.

\subsection{Climate simulation}

The model used in this study is the Kiel Climate Model (KCM; Park et al. 2009), which is a state-of-the-art coupled ocean-sea-ice-atmosphere general circulation model. The KCM comprises the ECHAM5 spectral atmospheric model and the NEMO (Nucleus for European Modelling of the Ocean) ocean-sea-ice general circulation model, coupled using the OASIS3 coupler. The horizontal resolution of ECHAM5 is T31 $\left(3.75^{\circ} \times 3.75^{\circ}\right)$, and in the vertical direction there are 19 levels up to $10 \mathrm{hPa}$. The horizontal resolution of NEMO is, on average, $1.3^{\circ}$, based on $2^{\circ}$ Mercator meshes with grid refinement in the tropical regions, where the meridional grid-point separation reaches $0.5^{\circ}$. NEMO assumes 31 vertical levels. More details on the model can be found in Park et al. (2009).

The transient simulation was initialized using output from an equilibrium simulation of the early Holocene forced by Earth's orbital parameters [eccentricity, obliquity and precession (Berger and Loutre 1991)] for $9.5 \mathrm{ka}$ BP, and then forced by varying the orbital parameters according to the respective period from 9.5 to $0 \mathrm{ka} \mathrm{BP}$ with a tenfold acceleration scheme (Lorenz and Lohmann 2004). Hence, the climate trends and feedbacks of the last 9500 years (9.5-0 ka BP) imposed by the external orbitally driven insolation changes were represented in the experiment by 950 model years in 10-year intervals. Other forcing factors apart from insolation forcing-for example, greenhouse gas concentrations, continental ice sheets and meltwater fluxes-were taken at pre-industrial (AD 1850) levels. In this regard, this approach is effectively a sensitivity test of

Table 1 Summary of the proxy records used in this study

\begin{tabular}{|c|c|c|c|c|c|c|c|}
\hline Site name & Core name & Lat $\left({ }^{\circ} \mathrm{N}\right)$ & Lon $\left({ }^{\circ} \mathrm{E}\right)$ & Proxy type & Dating method & $\begin{array}{l}\text { Number of dates } \\
\text { since } 9.5 \mathrm{ka} \mathrm{BP}\end{array}$ & References \\
\hline Qinghai Lake & QH-2000 & 36.67 & 100.51 & Pollen & AMS ${ }^{14} \mathrm{C}$ & 6 & Shen et al. (2005) \\
\hline Qinghai Lake & QH-2000 & 36.67 & 100.51 & Ostracod $\delta^{18} \mathrm{O}$ & AMS ${ }^{14} \mathrm{C}$ & 6 & Liu et al. (2007) \\
\hline Qinghai Lake & QH-2005 & 36.7 & 100.55 & Ostracod $\delta^{18} \mathrm{O}$ & AMS ${ }^{14} \mathrm{C}$ & 4 & Wang et al. (2011) \\
\hline Qinghai Lake & $1 \mathrm{Fs}$ & 36.81 & 100.14 & Ostracod $\delta^{18} \mathrm{O}$ & AMS ${ }^{14} \mathrm{C}$ & 23 & An et al. (2012) \\
\hline Luanhaizi Lake & LH & 37.59 & 101.35 & Pollen & AMS ${ }^{14} \mathrm{C}$ & 2 & $\begin{array}{l}\text { Herzschuh et al. } \\
\text { (2010), Wang et al. } \\
\text { (2014a) }\end{array}$ \\
\hline Dalianhai Lake & DLH & 36.25 & 100.41 & Pollen & AMS ${ }^{14} \mathrm{C}$ & 4 & Cheng et al. (2013) \\
\hline Gonghai Lake & $\mathrm{GH}$ & 38.9 & 112.23 & Pollen & AMS ${ }^{14} \mathrm{C}$ & 19 & Chen et al. $(2015 a, b)$ \\
\hline Tianchi Lake & $\mathrm{TC}$ & 35.26 & 106.31 & Pollen & AMS ${ }^{14} \mathrm{C}$ & 19 & Chen et al. $(2015 \mathrm{a}, \mathrm{b})$ \\
\hline Okinawa Trough & A7 & 27.82 & 126.98 & $\mathrm{Mg} / \mathrm{Ca}$ & AMS ${ }^{14} \mathrm{C}$ & 6 & Sun et al. (2005) \\
\hline
\end{tabular}


climate models to variations in insolation. More details on the model can be found in Jin et al. (2014).

The KCM climatology for present-day conditions has been validated against observations in Park et al. (2009) and Jin et al. (2014). Temperature trends from time slice simulations over the Holocene have been compared with proxy data in Schneider et al. (2010). The KCM reasonably well simulates the ASM precipitation during the Holocene (Jin et al. 2014; Dallmeyer et al. 2015). The KCM's rainfall is also consistent with that simulated by five other climate models in transient mode (Dallmeyer et al. 2015), which focused on trends in global zonal-mean June-July-August (JJA) precipitation and surface air temperature during the last $6 \mathrm{ka}$.

\section{Results}

On the northeastern Tibetan Plateau, the moisture (precipitation) changes during the Holocene revealed by the pollen records (Fig. 2a-c) were different from those revealed by the ostracod $\delta^{18} \mathrm{O}$ records (Fig. $2 \mathrm{e}-\mathrm{g}$ ). The pollen records suggested a wetting trend from 9.5 to $\sim 6.2 \mathrm{ka} \mathrm{BP}$ and a persistent drying trend thereafter, with the wettest interval in the middle Holocene. This wettest interval lagged the Northern Hemisphere summer insolation maximum (Fig. $2 \mathrm{~h}$ ) by $\sim 3.5 \mathrm{ka}$. However, the ostracod $\delta^{18} \mathrm{O}$ values shifted from low to high during the Holocene, implying a drying trend over this period according to the "amount effect", in which the amount of precipitation is inversely correlated with precipitation $\delta^{18} \mathrm{O}$ values (Dansgaard 1964). The moisture history derived from the ostracod $\delta^{18} \mathrm{O}$ records resembles that from stalagmite $\delta^{18} \mathrm{O}$ records, widespread across monsoonal China (Liu et al. 2015a; Cheng et al. 2016). Moreover, the ostracod $\delta^{18} \mathrm{O}$-based moisture (precipitation) variations closely followed the monsoon wind index and summer (June) insolation in the Northern Hemisphere during the Holocene (Fig. 2e-h).

The KCM-simulated summer precipitation on the northeastern Tibetan Plateau, averaged over the region $\left(35^{\circ}-45^{\circ} \mathrm{N}, 95^{\circ}-105^{\circ} \mathrm{E}\right)$, increased from $181 \mathrm{~mm}$ at $9.5 \mathrm{ka}$ BP to $191 \mathrm{~mm}$ at $6.2 \mathrm{ka} \mathrm{BP}$, and then decreased to $165 \mathrm{~mm}$ at $0 \mathrm{ka} \mathrm{BP}$ (Fig. 2d). The amount of summer precipitation at $0 \mathrm{ka} \mathrm{BP}$ based on the $\mathrm{KCM}$ simulation is quite close to

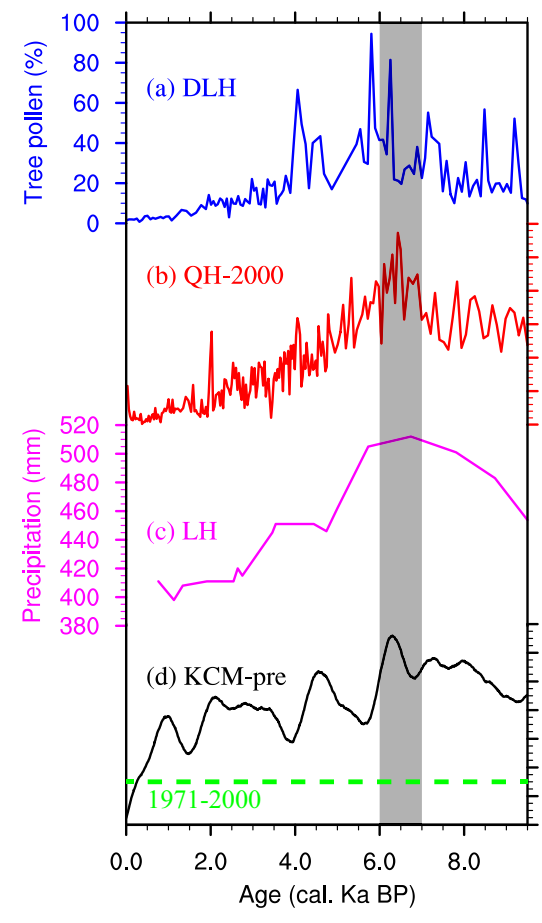

Fig. 2 Moisture changes during the Holocene on the northeastern Tibetan Plateau, from proxy records and climate simulation: a tree pollen percentages of Dalianhai Lake (Cheng et al. 2013); b tree pollen percentages from Core QH-2000 of Qinghai Lake (Shen et al. 2005); c annual precipitation reconstructed based on pollen assemblages from Luanhaizi Lake (Wang et al. 2014a); d summer rainfall averaged over the region $\left(35^{\circ}-45^{\circ} \mathrm{N}, 95^{\circ}-105^{\circ} \mathrm{E}\right)$, as simulated by the KCM (99-point Gaussian filter); The green line indicates the mean summer precipitation during 1971-2000 calculated based on

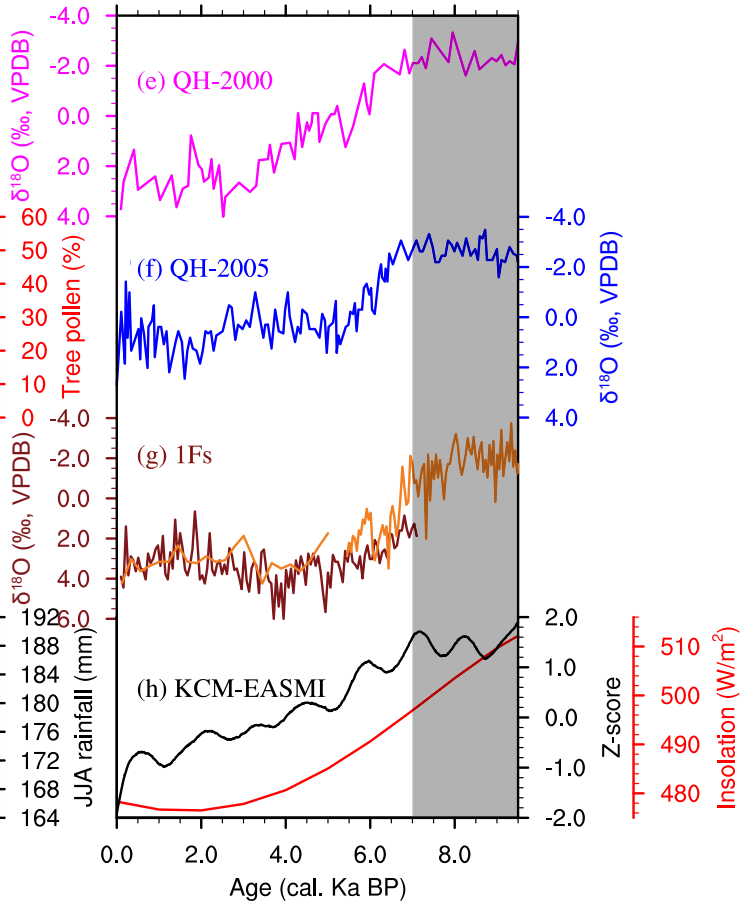

the meteorological data of 49 stations over the region $\left(35^{\circ}-45^{\circ} \mathrm{N}\right.$, $95^{\circ}-105^{\circ} \mathrm{E}$ ) (http://data.cma.cn). e ostracod $\delta^{18} \mathrm{O}$ records from Core QH-2000 of Qinghai Lake (Liu et al. 2007); f ostracod $\delta^{18} \mathrm{O}$ records from Core QH-2005 of Qinghai Lake (Wang et al. 2011); g ostra$\operatorname{cod} \delta^{18} \mathrm{O}$ records from Core 1Fs of Qinghai Lake (An et al. 2012); h EASM index [averaged summer meridional wind at $850 \mathrm{hPa}$ in East China $\left(30^{\circ}-45^{\circ} \mathrm{N}, 105^{\circ}-120^{\circ} \mathrm{E}\right)$ ], as simulated by the $\mathrm{KCM}$ (99-point Gaussian filter). June insolation at $45^{\circ} \mathrm{N}$ is plotted for comparison (Laskar et al. 2004) 
the observation value during 1971-2010 (Fig. 2d, green line), supporting the excellent ability of the KCM to simulate precipitation on the northeastern Tibetan Plateau. The model results agreed well with the pollen records, with the climatic optimum taking place over the middle Holocene (Fig. 2a-d). Model-proxy comparison therefore suggested the climatic optimum on the northeastern Tibetan Plateau lagged the peak summer insolation by $\sim 3.5 \mathrm{ka}$. It is therefore suggested that ostracod $\delta^{18} \mathrm{O}$ proxy records are not reasonable for measuring the amount of precipitation on the northeastern Tibetan Plateau, arguing the conclusion drawn by others (Lister et al. 1991; Liu et al. 2007; Wang et al. 2011; An et al. 2012).

\section{Discussion}

\subsection{Climatic significance of ostracod $\delta^{18} \mathrm{O}$ in Qinghai Lake}

According to the "amount effect" (Dansgaard 1964), the ostracod $\delta^{18} \mathrm{O}$ values of core sediments in Qinghai Lake, which receive the signal from precipitation $\delta^{18} \mathrm{O}$, are traditionally regarded as a proxy that can reflect the amount of precipitation over this region (Lister et al. 1991; Liu et al. 2007; Wang et al. 2011; An et al. 2012). However, observed precipitation $\delta^{18} \mathrm{O}$ values were found to be higher in the wet summer and lower in the dry winter during the period of 1986-2003 at Zhangye meteorological station, which is $200 \mathrm{~km}$ away from Qinghai Lake (Yao et al. 2013). This implies that changes in precipitation $\delta^{18} \mathrm{O}$ values on the northeastern Tibetan Plateau are probably not controlled by the "amount effect". Therefore, the ostracod $\delta^{18} \mathrm{O}$ in Qinghai Lake is probably not a proxy of precipitation on the northeastern Tibetan Plateau.

In addition to the "amount effect", it has also been suggested that changes in precipitation $\delta^{18} \mathrm{O}$ values are influenced by the moisture source of precipitation (LeGrande and Schmidt 2006; Breitenbach et al. 2010). We analysed the transport of water vapour for summer rainfall events at Xining meteorological station, $90 \mathrm{~km}$ away from Qinghai Lake, for the period 1954-2011 (provided by the China Meteorological Data Service Center, available online at http://data.cma.cn). The rainfall events were divided into three levels: rainfall greater than or equal to $25 \mathrm{~mm} /$ day $\left(\mathrm{R}_{25}, n=58\right.$ days); rainfall greater than or equal to $10 \mathrm{~mm} /$ day but less than $25 \mathrm{~mm} /$ day $\left(\mathrm{R}_{10-25}, n=349\right.$ days); and rainfall less than $10 \mathrm{~mm} /$ day $\left(\mathrm{R}_{10}, n=2089\right.$ days).

An anticyclonic anomaly was generated over Northeast Asia during the $R_{25}$ events compared to the $R_{10-25}$ events, bringing anomalous moisture from the northwestern Pacific to the northeastern Tibetan Plateau (Fig. 3a). These moisture sources also contributed considerably to
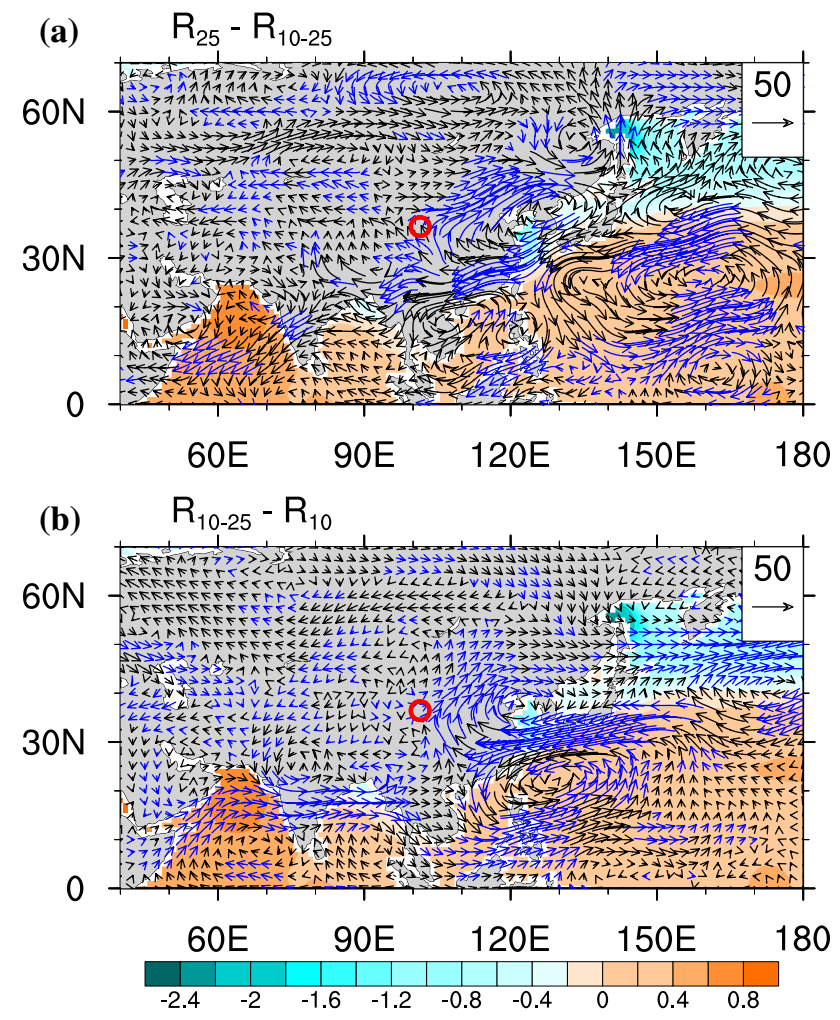

(c) Observed delta ${ }^{18} \mathrm{O}$

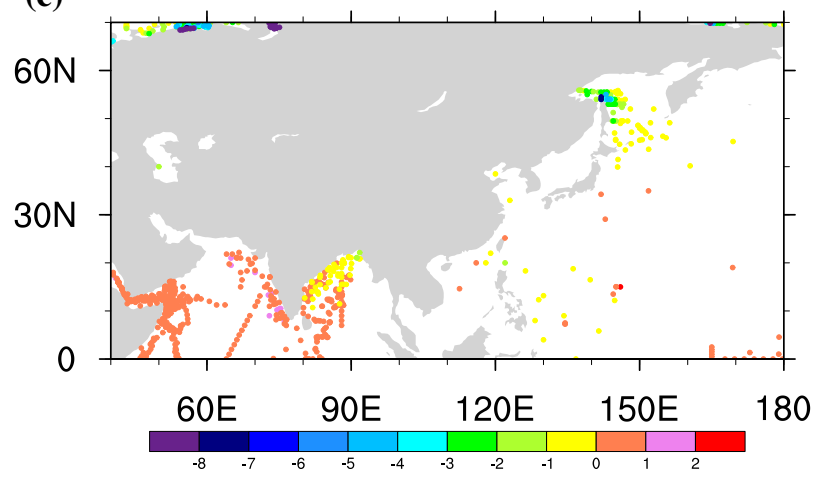

Fig. 3 Composite differences of the water vapour vertically integrated from the surface to $300 \mathrm{hPa}$, a between $\mathrm{R}_{25}$ events (rainfall days with greater than or equal to $25 \mathrm{~mm} /$ day) and $R_{10-25}$ events (rainfall days with greater than or equal to $10 \mathrm{~mm} /$ day but less than $25 \mathrm{~mm} /$ day), and $\mathbf{b}$ between $\mathrm{R}_{10-25}$ events (rainfall days with greater than or equal to $10 \mathrm{~mm} /$ day but less than $25 \mathrm{~mm} /$ day) and $\mathrm{R}_{10}$ events (rainfall days with less than $10 \mathrm{~mm} /$ day), at Xining weather station, in the summers of 1954-2011. Blue vectors indicate changes that are significant at the $90 \%$ confidence level. The circle indicates the location of Xining weather station. The colour shading shows the annual mean sea surface oxygen isotope ratio $\left(\delta^{18} \mathrm{O}\right)$ based on the global gridded data set of the oxygen isotopic composition in seawater (LeGrande and Schmidt 2006), which were calculated using $\mathbf{c}$ the observed $\delta^{18} \mathrm{O}$ values from the upper $5 \mathrm{~m}$ of the water column since about 1950 (Schmidt et al. 1999) 
the $\mathrm{R}_{10-25}$ events compared to the $\mathrm{R}_{10}$ events (Fig. $3 \mathrm{~b}$ ). That is, enhanced precipitation in Xining was associated with a stronger western Pacific subtropical high (WPSH) transporting the water vapour from the northwestern Pacific. However, the contributions of the westerly moisture transport from the North Atlantic and the southerly moisture transport from the Indian Ocean to the changes in precipitation at Xining meteorological station were not significant. Therefore, precipitation changes on the northeastern
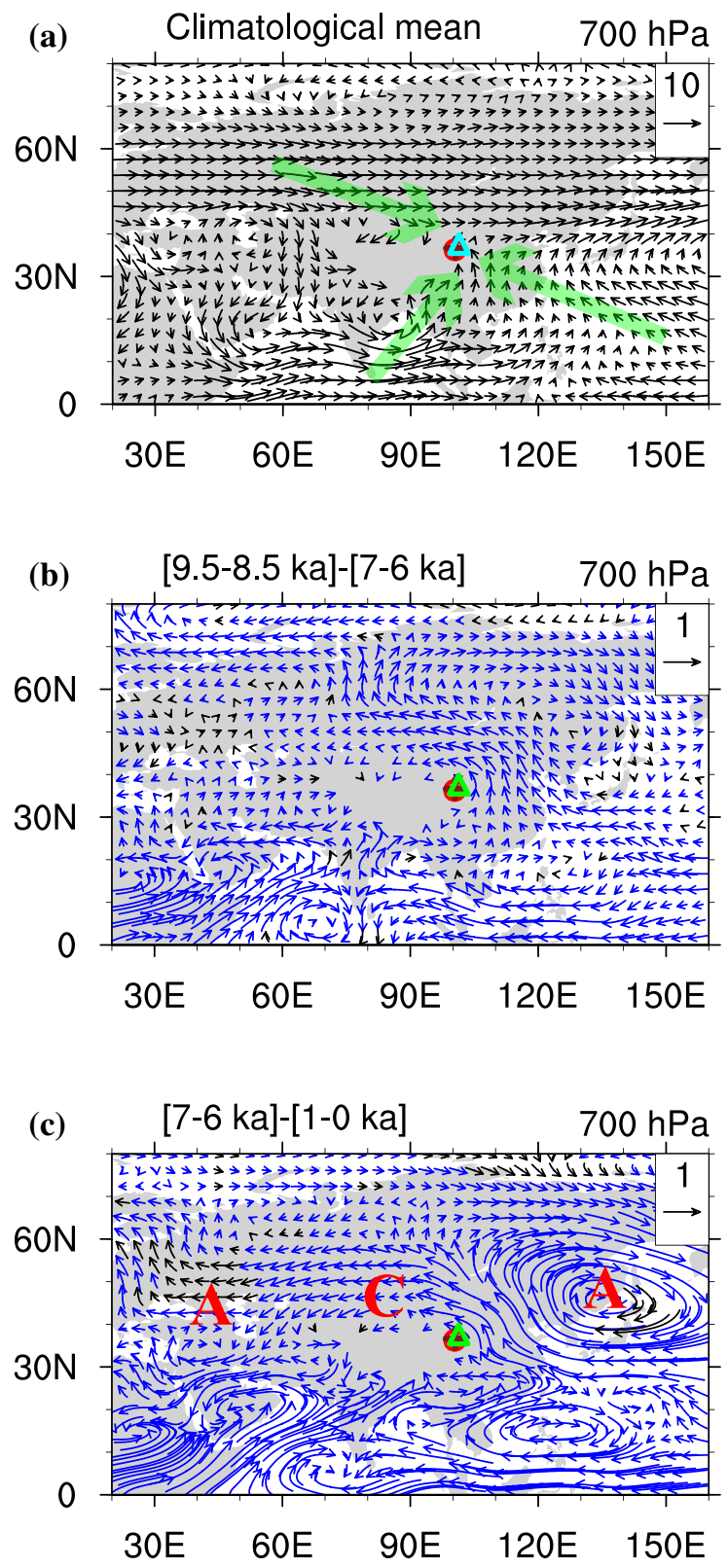

Fig. 4 a Simulated climatological mean summer wind fields $(\mathrm{m} / \mathrm{s})$ at $700 \mathrm{hPa}$. b Composite differences in summer wind fields at $700 \mathrm{hPa}$ between the periods of 9.5-8.5 and 7-6 ka BP. c Composite differences in summer wind fields at $700 \mathrm{hPa}$ between the periods of 7-6 and 1-0 ka BP. d-f As in a-c, but at $500 \mathrm{hPa}$. Blue vectors indicate
Tibetan Plateau are much more likely to be controlled by the EASM in the present-day climate.

A similar anticyclonic anomaly was also induced over Northeast Asia at $700 \mathrm{hPa}$ during the early (middle) Holocene compared to the middle (late) Holocene, in response to orbital forcing in the KCM transient simulation (Fig. 4b, c). This anticyclonic anomaly increased the southeasterly transport of moisture from the northwestern Pacific to the northeastern Tibetan Plateau (Fig. 4a-c). The southerly
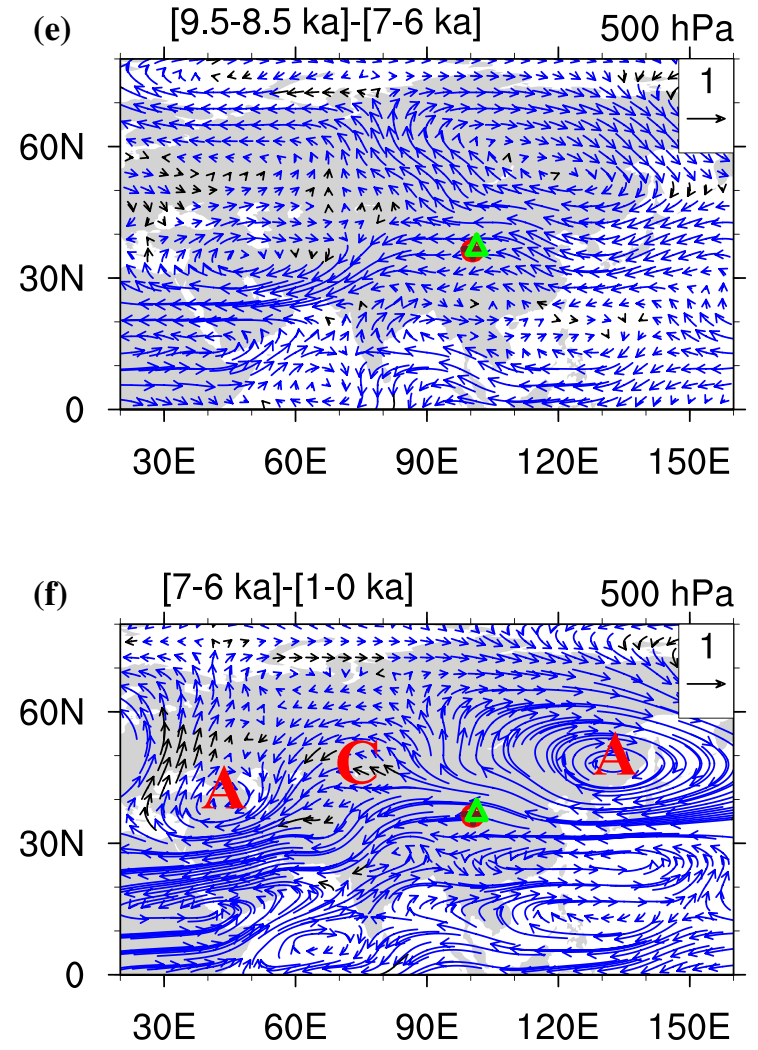

changes that are significant at the $95 \%$ confidence level. ' $A$ ' and ' $C$ ' indicate anticyclone and cyclone, respectively. The circle, cross and triangle indicate the locations of Dalianhai Lake, Qinghai Lake and Luanhaizi Lake, respectively. The green arrows indicate the wind directions. The pressure levels below surface pressure are omitted 
winds over the east of the Tibetan Plateau did not strengthen during the early (middle) Holocene compared to the middle (late) Holocene, in spite of an insolation-induced strong ISM (Fig. 4a-c). Therefore, the water vapour contributing to the precipitation changes on the northeastern Tibetan Plateau during the Holocene was probably transported by the EASM circulation from the northwestern Pacific, rather than by the ISM circulation from the Indian Ocean, as suggested by previous studies ( $\mathrm{Li}$ and $\mathrm{Xu}$ 2016; Li et al. 2016; Rao et al. 2016; Thomas et al. 2016).

Observed surface $\delta^{18} \mathrm{O}$ values were much lower in the mid-latitude North Pacific than in the tropical Pacific and Indian oceans (Fig. 3). Moisture evaporated from low $\delta^{18} \mathrm{O}$ water can decrease the precipitation $\delta^{18} \mathrm{O}$ values significantly (Breitenbach et al. 2010). Thus, it is expected that moisture from the mid-latitude North Pacific (Yellow Sea) causes lower values of precipitation $\delta^{18} \mathrm{O}$. Furthermore, the anticyclonic anomaly over Northeast Asia caused by insolation-induced enhanced EASM during the early Holocene (Fig. $4 \mathrm{~b}, \mathrm{c}$ ) was much stronger than that in the present-day climate (Fig. 3a, b). Therefore, the northeastern Tibetan Plateau could receive water vapour from the high-latitude North Pacific (Okhotsk Sea) during the early Holocene (Fig. 4b, c). Observed surface $\delta^{18} \mathrm{O}$ values were much lower $(\sim 2 \%$ ) $)$ in the Okhotsk Sea than in the Yellow Sea, with the greatest difference up to 7\%o (Fig. 3). In addition, the distance covered by the moisture transport from the high-latitude North Pacific is much longer than that from the mid-latitude North Pacific (Fig. 4). The long-distance moisture transport is associated with negative $\delta^{18} \mathrm{O}$ values (Tan 2014), which further reduced the $\delta^{18} \mathrm{O}$ values of the water vapour over the northeastern Tibetan Plateau during the early Holocene. These two factors can cover the most variability in the ostracod $\delta^{18} \mathrm{O}(\sim 4 \%)$ from Qinghai Lake during the Holocene. The surface $\delta^{18} \mathrm{O}$ values documented in planktonic foraminifera shells show no significant changes in the North Pacific Ocean throughout the Holocene (Ohkushi et al. 2003; Sun et al. 2005; Kubota et al. 2010). The weakened WPSH, which reduces the transport of water vapour from the high-latitude North Pacific, has probably been an important reason for the enrichment of ${ }^{18} \mathrm{O}$ in Qinghai Lake during the Holocene. The weakened WPSH is a vital component of the EASM system (Ding and Chan 2005). Therefore, the ostracod $\delta^{18} \mathrm{O}$ values probably reflect the strength of the EASM circulation.

Tan (2016) suggested that the WPSH is an important bridge connecting Chinese stalagmite $\delta^{18} \mathrm{O}$ to the circulation of the tropical Pacific (Tan 2014). Our results indicate that the WPSH might also bridge Chinese stalagmite (ostracod) $\delta^{18} \mathrm{O}$ with the mid-and high-latitude North Pacific. The asynchronous variations of ostracod $\delta^{18} \mathrm{O}$ and precipitation suggest that the precipitation changes on the northeastern Tibetan Plateau during the Holocene have not been completely controlled by the transport of water vapour related to the insolation-forced circulation of the EASM (Fig. 2h).

\subsection{Physical mechanisms responsible for the changes in precipitation on the northeastern Tibetan Plateau during the Holocene}

The simulated changes in summer precipitation on the northeastern Tibetan Plateau during the Holocene did not fully follow the summer insolation, with a delay of $\sim 3.5 \mathrm{ka}$ (Fig. 2). Previous studies have attributed this lag to the effects of slow ice-sheet melting and the discharge of meltwater into the North Atlantic during the early Holocene (Chen et al. 2015a, b; Li and Xu 2016). However, our simulation experiment considered orbital forcing only and did not take into account these effects. Therefore, internal feedbacks have likely played an important role during the Holocene in modulating the insolation forcing of summer precipitation changes on the northeastern Tibetan Plateau.

To explore the role of internal feedbacks to the precipitation changes on the northeastern Tibetan Plateau during the Holocene, we removed insolation forcing by deleting the linear trends of climate variabilities that approximate the general monotonic trend in summer insolation during the Holocene (Fig. 2h). The simulated summer precipitation on the northeastern Tibetan Plateau was negatively correlated with 700-hPa meridional winds over western Central Asia and the northwestern Pacific, and positively correlated with 700-hPa meridional winds over East Asia, on millennial time scales during the Holocene (Fig. 5a). In addition, the simulated summer precipitation was negatively associated with 700-hPa zonal winds over the Middle East, the east of Baikal Lake, East Asia, and the northwestern Pacific, on millennial time scales during the Holocene (Fig. 5b). This correlation pattern resembles a wave-like anomaly pattern at middle latitudes, shown by the composite difference in the summer wind fields at $700 \mathrm{hPa}$ between the middle and late Holocene (Fig. 4c). This wave-like pattern is conducive to the southward displacement of cold air and the westward transport of warm water vapour from the northwestern Pacific. When the cold air meets the warm and moist flow on the northeastern Tibetan Plateau, a frontal system will form, generating anomalous precipitation over the area. The southward displacement of cold air was especially obvious at $500 \mathrm{hPa}$ (Fig. 4f). However, no significant ridge and trough was induced over the west of the northeastern Tibetan Plateau during the early Holocene compared with the middle Holocene (Fig. 4b, e), in response to orbital forcing. This circulation pattern reduced frontal rainfall on the northeastern Tibetan Plateau during the early Holocene, in spite of enhanced westward transport of warm water vapour from the northwestern Pacific to this region 
(a) Corr (precip, va700)

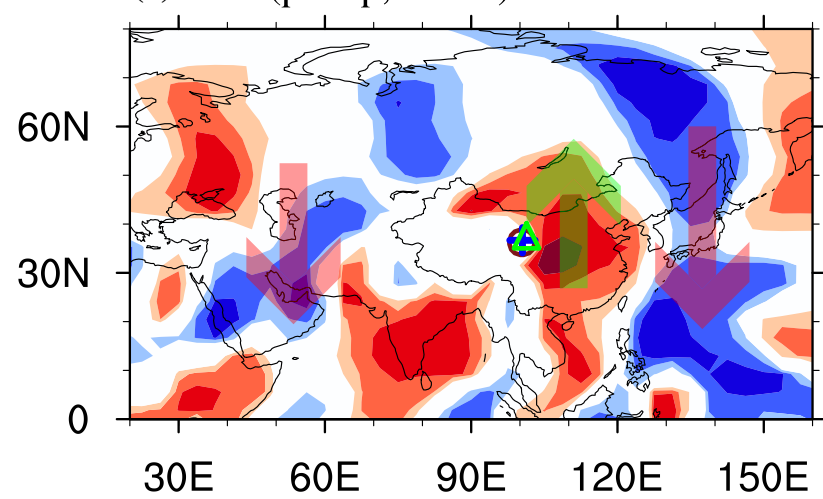

(b) Corr (precip, ua700)

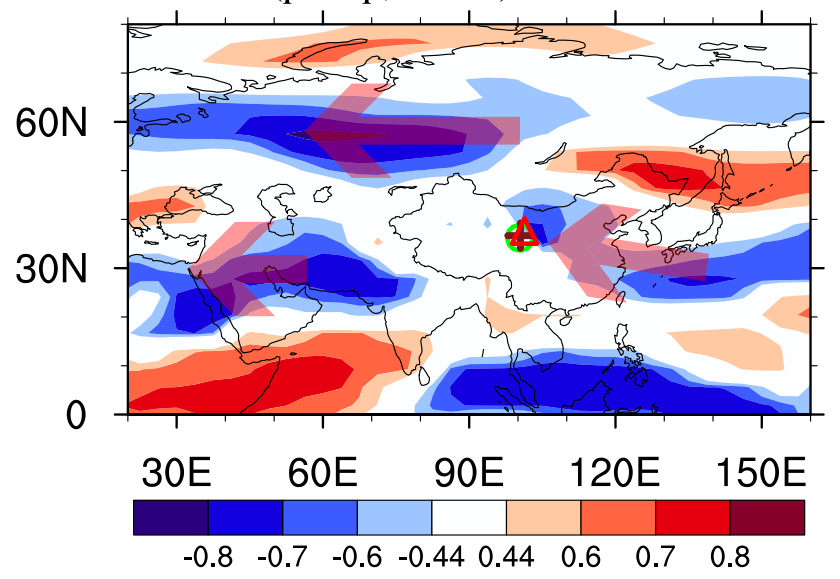

Fig. 5 Map showing correlations between the summer precipitation averaged over the region $\left(35^{\circ}-45^{\circ} \mathrm{N}, 95^{\circ}-105^{\circ} \mathrm{E}\right)$ and a meridional winds, and $\mathbf{b}$ zonal winds at $700 \mathrm{hPa}$ in summer on millennial time scales (99-point filtered and detrended). Areas in colour indicate that correlations are significant at the $95 \%$ confidence level, as estimated by Monte-Carlo experiments. The circle, cross and triangle indicate the locations of Dalianhai Lake, Qinghai Lake and Luanhaizi Lake, respectively. The arrows indicate the directions of the wind anomalies related to the summer precipitation. The pressure levels below surface pressure as a result of topography are omitted

(Fig. 4b). Since frontal rainfall is the major type of precipitation in summer in this area, the amount of precipitation was lower during the early Holocene than the middle Holocene (Fig. 2d).

The amplitude of the ridge-trough system was negatively related with the strength of the mid-latitude westerlies (Fig. 4c, f). The mid-latitude westerlies, which were negatively correlated with summer precipitation on the northeastern Tibetan Plateau (Fig. 6a), were determined by the meridional thermal difference between the middlelatitude and subpolar regions, ultimately influenced by the meridional insolation gradient. However, the simulated mid-latitude westerlies at $500 \mathrm{hPa}$ showed a slight weakening trend from 9.5 to $4.5 \mathrm{ka} \mathrm{BP}$, which inversely
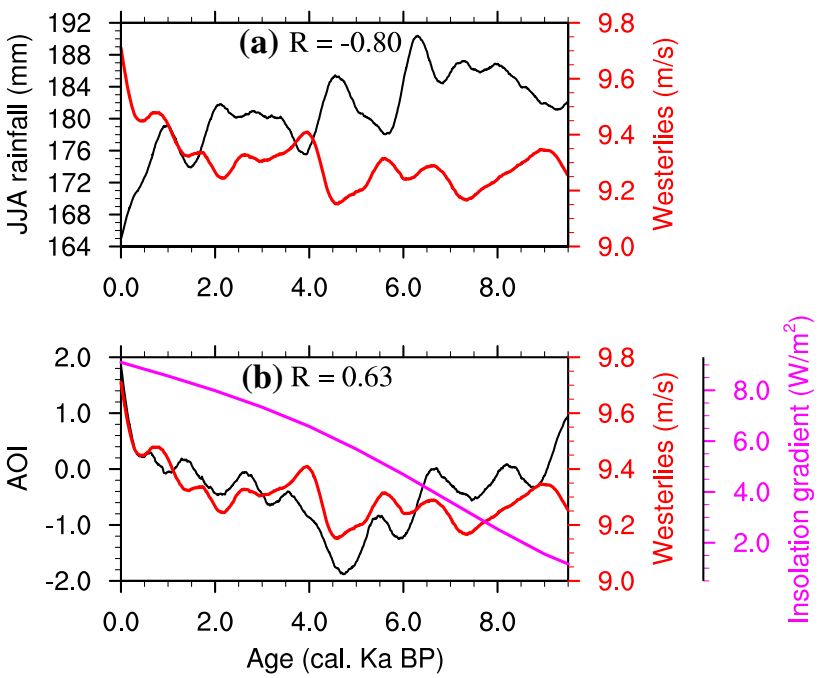

Fig. 6 a Comparisons between summer rainfall (99-point Gaussian filter, black line) on the northeastern Tibetan Plateau and the strength of the westerlies (99-point Gaussian filter, red line) in the region $\left(30^{\circ}-60^{\circ} \mathrm{N}, 0^{\circ}-80^{\circ} \mathrm{E}\right)$ at $500 \mathrm{hPa}$, based on the KCM simulation. b Comparison between the Arctic Oscillation index (AOI) (99-point Gaussian filter, black line) and the strength of the westerlies (99point Gaussian filter, red line $)$ in the region $\left(30^{\circ}-60^{\circ} \mathrm{N}, 0^{\circ}-80^{\circ} \mathrm{E}\right)$ at $500 \mathrm{hPa}$, based on the KCM simulation. The AOI is defined as the difference in the normalized monthly zonal-mean sea level pressure between $35^{\circ} \mathrm{N}$ and $65^{\circ} \mathrm{N}$ ( $\mathrm{Li}$ and Wang 2003). The difference in June insolation between $30^{\circ} \mathrm{N}$ and $60^{\circ} \mathrm{N}$ (magenta line) is plotted for comparison

followed the insolation difference between $30^{\circ} \mathrm{N}$ and $60^{\circ} \mathrm{N}$ (Fig. 6b). This divergence was probably affected by the Arctic Oscillation (AO), which was positively correlated with the strength of the westerlies at $500 \mathrm{hPa}$ (Fig. 6b); a negative phase of the $\mathrm{AO}$ is conductive to the development of a ridge-trough system at middle latitudes (Blunden et al. 2011). The strength of the AO shifted from positive phase during the early Holocene to negative phase during the middle Holocene, and then returned to positive phase during the late Holocene-a finding that agrees well with a proxy record identified in Arctic sea-ice drift (Darby et al. 2012). The positive phase of the AO during the early Holocene was able to overwhelm the insolation forcing, causing a slight decreasing trend in the strength of the mid-latitude westerlies at $500 \mathrm{hPa}$ during this period (Fig. 6b).

The variation of summer precipitation on the northeastern Tibetan Plateau during the Holocene was a result of the interaction between the mid-latitude westerlies and the EASM circulation. The relatively weaker precipitation during the early Holocene, as compared with the middle Holocene, was caused by stronger mid-latitude westerlies resulting from a positive phase of the AO. Therefore, the lagged response of the peak precipitation on the northeastern Tibetan Plateau to the summer insolation maximum during the Holocene was probably caused by the AO. 
In addition, the precipitation changes on the northeastern Tibetan Plateau according to the pollen records were inversely correlated with the $\mathrm{Mg} / \mathrm{Ca}$-based sea-surface temperatures (SSTs) in the northwestern Pacific during the Holocene (Fig. 7). The simulated summer SSTs in the northwestern Pacific $\left(15^{\circ}-30^{\circ} \mathrm{N}, 120^{\circ}-150^{\circ} \mathrm{E}\right)$ match well with the $\mathrm{Mg} / \mathrm{Ca}$ record, showing a cooling trend from the early to middle Holocene and a consistent warming trend thereafter (Fig. 8a). The simulation results also revealed a significantly negative correlation $(r=-0.79, P<0.05)$ between the northwestern Pacific SSTs and summer precipitation on millennial time scales (Fig. 8b). Their relationship is independent from the orbital forcing, as the correlation $(r=-0.68)$ is still significant at the $95 \%$ confidence level after removing the millennial-scale trend. We further applied the generalized difference method to remove the influence of autocorrelation on the $p$-values. The correlation coefficient between the differential sequences is 0.51 $(P<0.05)$, indicating an internal relationship between them.

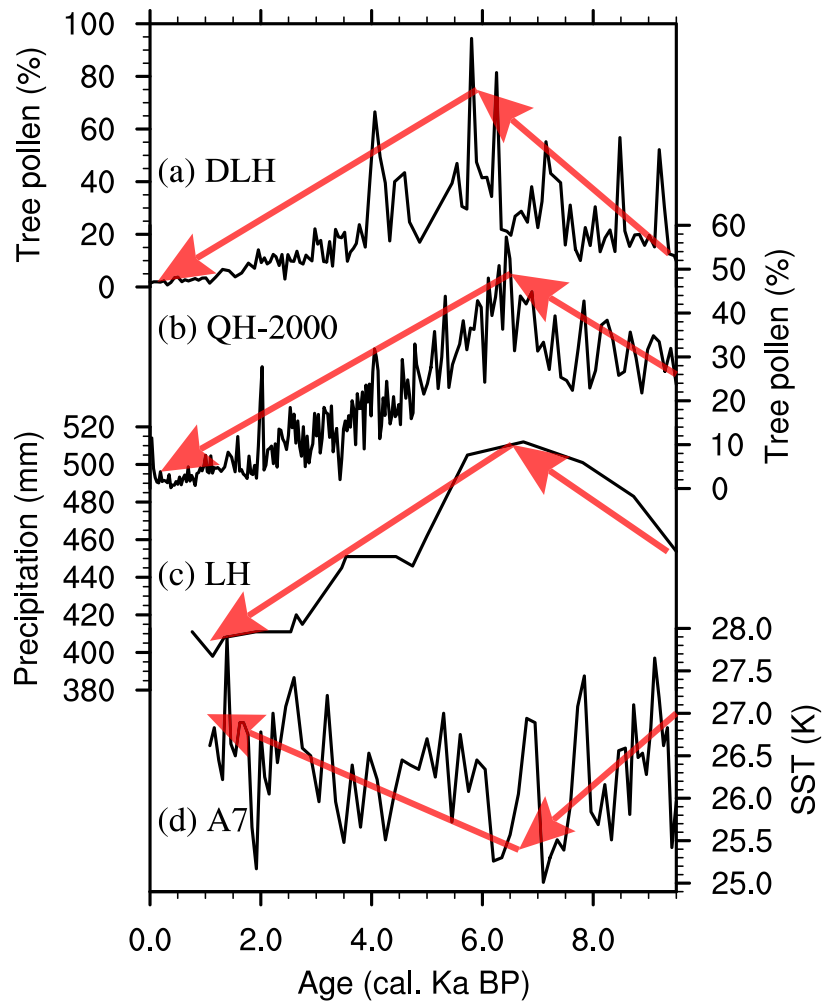

Fig. 7 Comparison between the moisture changes on the northeastern Tibetan Plateau $(\mathbf{a}-\mathbf{c})$ and $\mathbf{d}$ northwestern Pacific SSTs: a tree pollen percentages of Dalianhai Lake (Cheng et al. 2013); b tree pollen percentages from Core QH-2000 of Qinghai Lake (Shen et al. 2005); c annual precipitation reconstructed based on pollen assemblages from Luanhaizi Lake (Wang et al. 2014a); d northwestern Pacific SSTs derived from the $\mathrm{Mg} / \mathrm{Ca}$ of core A7 (Sun et al. 2005)
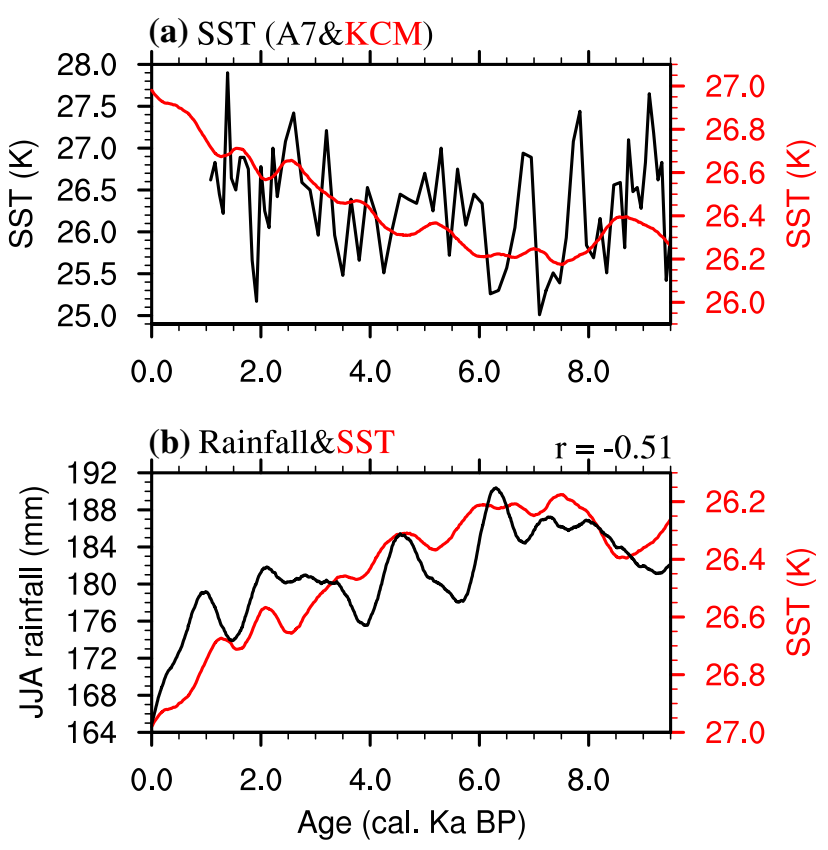

Fig. 8 a Comparison of northwestern Pacific SSTs between the proxy record (black line) and $\mathrm{KCM}$ simulation result (red line). The $\mathrm{KCM}$ simulation result is the mean summer SSTs averaged over the region $\left(15^{\circ}-30^{\circ} \mathrm{N}, 120^{\circ}-150^{\circ} \mathrm{E}\right)(99$-point Gaussian filter). b Comparison between northwestern Pacific SSTs (99-point Gaussian filter, red line) and summer rainfall (99-point Gaussian filter, red line) over the northeastern Tibetan Plateau, based on the KCM simulation

Anomalously warm SSTs over the northwestern Pacific tended to increase the integrated tropospheric air temperature (TT) over the western Pacific and Indian oceans (Fig. 9a). In addition, the TT over East Asia was negatively correlated with the northwestern Pacific SSTs (Fig. 9a). That is, anomalously warm northwestern Pacific SSTs would have decreased the meridional thermal contrast between East Asia and the tropical western Pacific. This meridional thermal contrast is suggested to be the cause of the EASM (Zhou and Zou 2010), which induces easterly wind anomalies over East Asia transporting water vapour from the northwestern Pacific to the northeastern Tibetan Plateau (Fig. 9b). Therefore, warm SST anomalies in the northwestern Pacific decreased this water vapour transport, and the resultant precipitation (Figs. 7, 8b). In this way, summer precipitation changes during the Holocene have been modulated by the SSTs in the northwestern Pacific.

\subsection{Possible reason for the mismatch between the simulation and proxy during the late Holocene}

During the late Holocene, especially the last millennium, pollen records indicated a remarkably stable climate on the northeastern Tibetan Plateau (Fig. 2a-c). In the contrast, 
(a) Corr (NWPSST, TT)

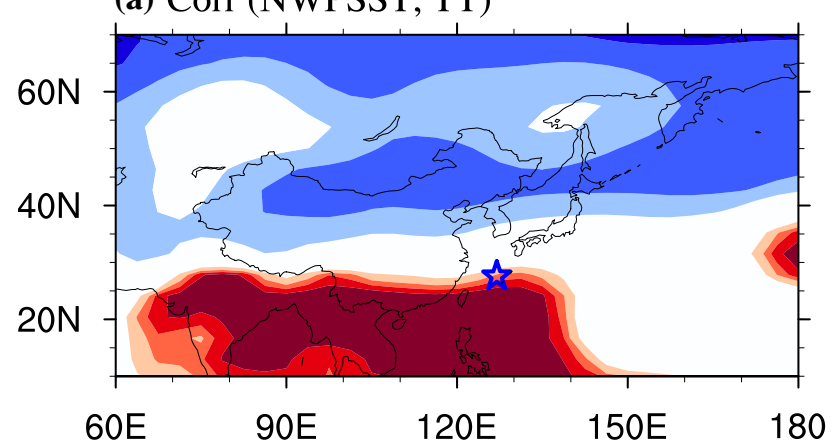

(b) Corr (NWPSST, ua700)

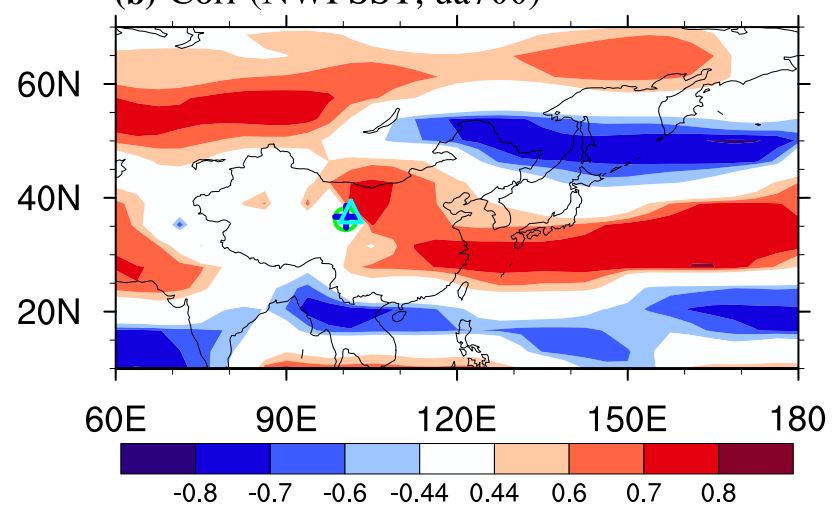

Fig. 9 Map showing the correlations between northwestern Pacific SSTs and a tropospheric temperature (1000-200 hPa), and b zonal wind at $700 \mathrm{hPa}$, in summer on millennial time scales (99-point filtered and detrended). Areas in colour indicate that correlations are significant at the $95 \%$ confidence level, as estimated by Monte-Carlo experiments. The star, circle, cross and triangle indicate the locations of A7, Dalianhai Lake, Qinghai Lake and Luanhaizi Lake, respectively. The pressure levels below surface pressure as a result of topography are omitted

the KCM simulated a quick decrease in the summer precipitation on the northeastern Tibetan Plateau during this period (Fig. 2d). Archaeological research found that there was an increasing intensity of human activities since $3.6 \mathrm{ka}$ BP over this area (Chen et al. 2015a, b). This area is an important sector of the ancient Silk Road. Strong human activities would have remarkably altered the natural vegetation, causing a broken connection between the climate and vegetation evolution.

By comparison, EASM precipitation changes revealed from two remote alpine lakes, Tianchi Lake (Fig. 10a) and Gonghai Lake (Chen et al. 2015a, b) (Fig. 10b), on the Chinese Loess Plateau experienced a sharp decrease during the last millennium, matching well with the $\mathrm{KCM}$ simulation results (Fig. 10c). These two lakes are remote, and remain largely untouched during the historical period. Specially, Gonghai Lake is located in Guancen Mountain where was a royal forest, and therefore was highly protected during the historical period. In addition, diatom records suggested

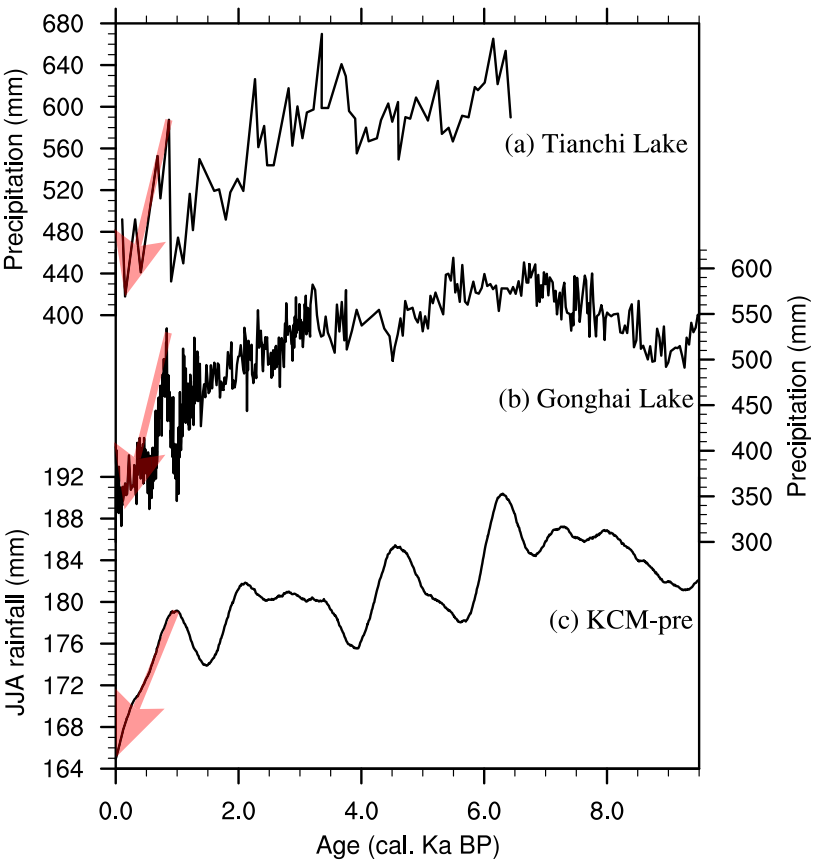

Fig. 10 Comparison of the KCM-simulated summer precipitation on the northeastern Tibetan Plateau (c) and pollen-based EASM precipitation (a) from Tianchi Lake (Chen et al. 2015a, b), and b from Gonghai Lake (Chen et al. 2015a, b) on the Chinese Loess Plateau

that Gonghai Lake had not been significantly disturbed by human activities during the historical period (Liu et al. 2017). Therefore, EASM history documented in Gonghai Lake mainly reflects actual climate change. However, pollen records imprinted by significant human influence fail to indicate moisture change, leading to a mismatch between the proxy and simulation during the late Holocene (Fig. 2).

\section{Conclusions}

The temporal evolution of precipitation changes on the northeastern Tibetan Plateau during the Holocene and its forcing mechanisms are by no means properly understood. To help address the knowledge gap, this study investigated this topic through combining proxy records with the results from a transient simulation forced by orbital variations in a coupled ocean-sea-ice-atmosphere general circulation model.

The ostracod $\delta^{18} \mathrm{O}$ records from Qinghai Lake suggested that the northeastern Tibetan Plateau has experienced a persistent drying trend during the Holocene, following the trend of declining summer insolation in the Northern Hemisphere. However, the pollen records from Qinghai Lake and surrounding lakes suggested that the early Holocene was drier than the middle Holocene, showing a lagged response to solar variability. The simulation results match the pollen 
records well. The model-proxy comparison therefore indicates that the ostracod $\delta^{18} \mathrm{O}$ is not a proper proxy record of the amount of precipitation on the northeastern Tibetan Plateau. Further study revealed that the ostracod (precipitation) $\delta^{18} \mathrm{O}$ in Qinghai Lake might reflect the water vapour from the high-latitude North Pacific, in which the $\delta^{18} \mathrm{O}$ values are much lower than they are in other sea areas, e.g., the low-and mid-Pacific and Indian oceans. Reduced water vapour from the high-latitude North Pacific, resulting from insolation-induced weakening monsoon circulation, was probably an important factor contributing to the increasing values of ostracod $\delta^{18} \mathrm{O}$ in Qinghai Lake during the Holocene. In addition, the decreased distance of the moisture transport further promoted the enrichment of $\delta^{18} \mathrm{O}$ in Lake Qinghai during the Holocene.

The changes in summer precipitation on the northeastern Tibetan Plateau during the Holocene have been controlled by the interaction between the EASM circulation and mid-latitude westerlies. A stronger EASM circulation, related to the insolation-induced sea-land thermal contrast, enhances the transport of water vapour from the northwestern Pacific to the northeastern Tibetan Plateau. Weaker mid-latitude westerlies generate troughs and ridges, leading to the invasion of cold air into the northeastern Tibetan Plateau. The mid-latitude westerlies, meanwhile, have been jointly controlled during the Holocene by the meridional thermal contrast triggered by the insolation gradient and the AO. A positive phase of the AO during the early Holocene overwhelmed the effect of the weak meridional insolation gradient, leading to relatively stronger mid-latitude westerlies in this period compared to the middle Holocene. These relatively stronger mid-latitude westerlies ultimately reduced the amounts of precipitation during the early Holocene, in spite of being affected by the most powerful EASM throughout the Holocene. Therefore, the AO has played an important role during the Holocene in the lagged response of summer precipitation to insolation forcing. In addition, the SSTs in the northwestern Pacific have further modulated summer precipitation through their effect on the circulation of the EASM.

\footnotetext{
Acknowledgements This study was jointly supported by the National Basic Research Program of China (Grant No. 2016YFA0600503), the National Natural Science Foundation of China (NSFC) (Grant Nos. 41690111 and 41275071), the National Postdoctoral Program for Innovative Talents (Grant No. BX201600068), and the China Postdoctoral Science Foundation (Grant No. 2017M610318). LJ acknowledges support from a Deutsche Forschungsgemeinschaft (DFG) grant through the Cluster of Excellence's Future Ocean initiative (EXC 80/1) in a project which was lead by Prof. Dr. Birgit Schneider of Christian-Albrechts-Universität zu Kiel. Modeling experiments using the KCM were performed at the Kiel University Computer Center, Kiel, Germany. W. Park and M. Latif of GEOMAR Helmholtz-Zentrum für Ozeanforschung Kiel are kindly thanked for their help and thoughtful discussions on KCM simulation methods.
}

Open Access This article is distributed under the terms of the Creative Commons Attribution 4.0 International License (http:// creativecommons.org/licenses/by/4.0/), which permits unrestricted use, distribution, and reproduction in any medium, provided you give appropriate credit to the original author(s) and the source, provide a link to the Creative Commons license, and indicate if changes were made.

\section{References}

An Z, Colman SM, Zhou W, Li X, Brown ET, Jull AJ, Cai Y, Huang Y, Lu X, Chang H, Song Y, Sun Y, Xu H, Liu W, Jin Z, Liu X, Cheng P, Liu Y, Ai L, Li X, Liu X, Yan L, Shi Z, Wang X, Wu F, Qiang X, Dong J, Lu F, Xu X (2012) Interplay between the Westerlies and Asian monsoon recorded in Lake Qinghai sediments since $32 \mathrm{ka}$. Sci Rep 2:619. doi:10.1038/srep00619

Berger A, Loutre MF (1991) Insolation values for the climate of the last 10 million years. Quat Sci Rev 10:297-317

Blunden J, Arndt D, Baringer M (2011) State of the Climate in 2010. Bull Am Meteorol Soc 92(6):S1-S236

Breitenbach SFM, Adkins JF, Meyer H, Marwan N, Kumar KK, Haug GH (2010) Strong influence of water vapor source dynamics on stable isotopes in precipitation observed in Southern Meghalaya, NE India. Earth Planet Sci Lett 292:212-220

Chao W (2000) Multiple quasi equilibria of the ITCZ and the origin of monsoon onset. J Atmos Sci 57(5):641-652

Chen F, Dong G, Zhang D, Liu X, Jia X, An C, Ma M, Xie Y, Barton L, Ren X, Zhao Z, Wu X, Jones MK (2015a) Agriculture facilitated permanent human occupation of the Tibetan Plateau after 3600 B.P. Science 347(6219):248-250

Chen F, Xu Q, Chen J, Birks HJB, Liu J, Zhang S, Jin L, An C, Telford RJ, Cao X, Wang Z, Zhang X, Selvaraj K, Lu H, Li Y, Zheng Z, Wang H, Zhou A, Dong G, Zhang J, Huang X, Bloemendal J, Rao Z (2015b) East Asian summer monsoon precipitation variability since the last deglaciation. Sci Rep 5:11186. doi:10.1038/srep11186

Chen F, Wu D, Chen J, Zhou A, Yu J, Shen J, Wang S, Huang X (2016) Holocene moisture and East Asian summer monsoon evolution in the northeastern Tibetan Plateau recorded by Lake Qinghai and its environs: a review of conflicting proxies. Quat Sci Rev 154:111-129

Cheng B, Chen F, Zhang J (2013) Palaeovegetational and palaeoenvironmental changes since the last deglacial in Gonghe Basin, northeast Tibetan Plateau. J Geogr Sci 23:136-146

Cheng H, Edwards RL, Sinha A, Spötl C, Yi L, Chen S, Kelly M, Kathayat G, Wang X, Li X, Kong X, Wang Y, Ning Y, Zhang H (2016) The Asian monsoon over the past 640,000 years and ice age terminations. Nature 534:640-646

Colman SM, Yu S-Y, An Z, Shen J, Henderson ACG (2007) Late Cenozoic climate changes in China's western interior: a review of research on Lake Qinghai and comparison with other records. Quat Sci Rev 26:2281-2300

Dallmeyer A, Claussen M, Fischer N, Haberkorn K, Wagner S, Pfeiffer M, Jin L, Khon V, Wang Y, Herzschuh U (2015) The evolution of sub-monsoon systems in the Afro-Asian monsoon region during the Holocene-comparison of different transient climate model simulations. Clim Past 10:2293-2353

Dansgaard W (1964) Stable isotopes in precipitation. Tellus 16:436-468

Darby DA, Ortiz JD, Grosch CE, Lund SP (2012) 1500-year cycle in the Arctic Oscillation identified in Holocene Arctic sea-ice drift. Nat Geosci 5:897-900

Ding Y, Chan JCL (2005) The East Asian summer monsoon: an overview. Meteorol Atmos Phys 89:117-142 
Fleitmann D, Burns SJ, Mangini A, Mudelsee M, Kramers J, Villa I, Neff U, Al-Subbary AA, Buettner A, Hippler D, Matter A (2007) Holocene ITCZ and Indian monsoon dynamics recorded in stalagmites from Oman and Yemen (Socotra). Quat Sci Rev 26:170-188

Herzschuh U, Birks HJB, Mischke S, Zhang C, Böhner J (2010) A modern pollen-climate calibration set based on lake sediments from the tibetan plateau and its application to a late quaternary pollen record from the qilian mountains. J Biogeogr 37:752-766

Ji J, Shen J, Balsam W, Chen J, Liu L, Liu X (2005) Asian monsoon oscillations in the northeastern Qinghai-Tibet Plateau since the late glacial as interpreted from visible reflectance of Qinghai Lake sediments. Earth Planet Sci Lett 233:61-70

Jin L, Schneider B, Park W, Latif M, Khon V, Zhang X (2014) The spatial-temporal patterns of Asian summer monsoon precipitation in response to Holocene insolation change: a model-data synthesis. Quat Sci Rev 85:47-62

Johnson KR, Ingram BL (2004) Spatial and temporal variability in the stable isotope systematics of modern precipitation in China: implications for paleoclimate reconstructions. Earth Planet Sci Lett 220:365-377

Kalnay E, Kanamitsu M, Kirtler R, Collins W, Deaven D, Gandin L, Iredell M, Saha S, White G, Woollen J, Zhu Y, Chelliah M, Ebisuzaki W, Higgins W, Janowiak J, Mo KC, Ropelewski C, Wang J, Leetma A, Reynolds R, Jenne R, Joseph D (1996) The NCEP/NCAR 40-year reanalysis project. Bull Am Meteor Soc 77:437-471

Kubota Y, Kimoto K, Tada R, Oda H, Yokoyama Y, Matsuzaki H (2010) Variations of East Asian summer monsoon since the last deglaciation based on $\mathrm{Mg} / \mathrm{Ca}$ and oxygen isotope of planktic foraminifera in the northern East China Sea. Paleoceanography 25:PA4205. doi:10.1029/2009PA001891

Laskar J, Robutel P, Joutel F, Gastineau M, Correia ACM, Levrard B (2004) A long term numerical solution for the insolation quantities of the Earth. Astron Astrophys 428:261-285

LeGrande AN, Schmidt GA (2006) Global gridded data set of the oxygen isotopic composition in seawater. Geophys Res Lett 33:L12604. doi:10.1029/2006GL026011

Li J, Wang JXL (2003) A modified zonal index and its physical sense. Geophys Res Lett 30:1632. doi:10.1029/2003GL017441

Li Y, Xu L (2016) Asynchronous Holocene Asian monsoon vapor transport and precipitation. Palaeogeogr Palaeoclimatol Palaeoecol 461:195-200

Li Y, Zhang C, Wang Y (2016) The verification of millennial-scale monsoon water vapor transport channel in northwest China. J Hydrol 536:273-283

Lister GS, Kelts K, Chen KZ, Yu JQ, Niessen F (1991) Lake Qinghai, China: closed basin lake levels and the oxygen isotope record for Ostracoda since the latest Pleistocene. Palaeogeogr Palaeoclimatol Palaeoecol 84(1-4):141-162

Liu X, Shen J, Wang S, Wang Y, Liu W (2007) Southwest monsoon changes indicated by oxygen isotope of ostracode shells from sediments in Lake Qinghai since the late Glacial. Chin Sci Bull 52:539-544

Liu W, Li X, Zhang L, An Z, Xu L (2009) Evaluation of oxygen isotopes in carbonate as an indicator of lake evolution in arid areas: The modern Qinghai Lake, Qinghai-Tibet Plateau. Chem Geol 268:126-136

Liu W, Li X, An Z, Xu L, Zhang Q (2013) Total organic carbon isotopes: a novel proxy of lake level from Lake Qinghai in the Qinghai-Tibet Plateau, China. Chem Geol 347:153-160

Liu Z, Wen X, Brady EC, Otto-Bliesner B, Yu G, Lu H, Cheng H, Wang Y, Zheng W, Ding Y, Edwards RL, Cheng J, Liu W, Yang $\mathrm{H}$ (2014a) Chinese cave records and the East Asia Summer Monsoon. Quat Sci Rev 83:115-128
Liu X, Colman SM, Brown ET, Henderson ACG, Werne JP, Holmes JA (2014b) Abrupt deglaciation on the northeastern Tibetan Plateau: evidence from Lake Qinghai. J Paleolimnol 51:223-240

Liu J, Chen J, Zhang X, Li Y, Rao Z, Chen F (2015a) Holocene East Asian summer monsoon records in northern China and their inconsistency with Chinese stalagmite $\delta^{18} \mathrm{O}$ records. Earth-Science Rev 148:194-208

Liu X, Lai Z, Madsen D, Zeng F (2015b) Last deglacial and Holocene lake level variations of Qinghai Lake. J Quat Sci 30:245-257

Liu J, Rühland KM, Chen J, Xu Y, Chen S, Chen Q, Huang W, Xu Q, Chen F, Smol JP (2017) Aerosol-weakened summer monsoons decrease lake fertilization on the Chinese Loess Plateau. Nat Clim Change 7:190-194

Lorenz S, Lohmann G (2004) Acceleration technique for Milankovitch type forcing in a coupled atmosphere-ocean circulation model: method and application for the Holocene. Clim Dyn 23:727-743

Lu H, Zhao C, Joseph M, Yi S, Zhao H, Zhou Y, Ji J, James S, Wang C (2010) Holocene climatic changes revealed by aeolian deposits from the Qinghai Lake area (northeastern Qinghai-Tibetan Plateau) and possible forcing mechanisms. Holocene 21(2):297-304

Ohkushi K, Itaki T, Nemoto N (2003) Last Glacial-Holocene change in intermediate-water ventilation in the Northwestern Pacific. Quat Sci Rev 22:1477-1484

Park W, Keenlyside N, Latif M, Ströh A, Redler R, Roeckner E, Madec G (2009) Tropical Pacific climate and its response to global warming in the Kiel climate model. J Clim 22:71-92

Rao Z, Qiang M, Jia G, Li Y, Dan D, Chen F (2016) A 15 ka lake water $\delta \mathrm{D}$ record from Genggahai Lake, northeastern Tibetan Plateau, and its paleoclimatic significance. Org Geochem 97:5-16

Schmidt GA, Bigg GR, Rohling EJ (1999) Global seawater oxygen-18 database, http://data.giss.nasa.gov/o18data/. NASA Goddard Inst of Space Sci, New York

Schneider B, Leduc G, Park W (2010) Disentangling seasonal signals in Holocene climate trends by satellite-model-proxy integration. Paleoceanography 25(4):PA4217. doi:10.1029/2009PA001893

Shen J, Liu X, Wang S, Ryo M (2005) Palaeoclimatic changes in the Qinghai Lake area during the last 18,000 years. Quat Int 136:131-140

Sun Y, Oppo DW, Xiang R, Liu W, Gao S (2005) Last deglaciation in the Okinawa Trough: Subtropical northwest Pacific link to Northern Hemisphere and tropical climate. Paleoceanography 20:PA4005. doi:10.1029/2004PA001061

Tan M (2014) Circulation effect: response of precipitation $\delta^{18} \mathrm{O}$ to the ENSO cycle in monsoon regions of China. Clim Dyn 42:1067-1077

Tan M (2016) Circulation background of climate patterns in the past millennium: Uncertainty analysis and re-reconstruction of ENSO-like state. Sci China Earth Sci 59:1225-1241

Thomas EK, Huang Y, Clemens SC, Colman SM, Morrill C, Wegener P, Zhao J (2016) Changes in dominant moisture sources and the consequences for hydroclimate on the northeastern Tibetan Plateau during the past $32 \mathrm{kyr}$. Quat Sci Rev 131:157-167

Wang B (ed) (2006) The Asian monsoon. Springer, Berlin

Wang Y, Shen J, Xu X, Liu X, Sirocko F, Zhang E, Ji J (2011) Environmental changes during the past $13500 \mathrm{cal}$. a BP deduced from lacustrine sediment records of Lake Qinghai, China. Chin J Geochem 30:479-489

Wang Y, Herzschuh U, Shumilovskikh LS, Mischke S, Birks HJB, Wischnewski J, Böhner J, Schlütz F, Lehmkuhl F, Diekmann B, Wünnemann B, Zhang C (2014a) Quantitative reconstruction of precipitation changes on the NE Tibetan Plateau since the Last Glacial Maximum-extending the concept of pollen source area to pollen-based climate reconstructions from large lakes. Clim Past 10:21-39 
Wang H, Dong H, Zhang C, Jiang H, Zhao M, Liu Z, Lai Z, Liu W (2014b) Water depth affecting thaumarchaeol production in Lake Qinghai, northeastern Qinghai-Tibetan plateau: implications for paleo lake levels and paleoclimate. Chem Geol 368:76-84

Wei K, Gasse F (1999) Oxygen isotopes in lacustrine carbonates of West China revisited: implications for post glacial changes in summer monsoon circulation. Quat Sci Rev 18:1315-1334

Xu H, Hou Z, Ai L, Tan L (2007) Precipitation at Lake Qinghai, NE Qinghai-Tibet Plateau, and its relation to Asian summer monsoons on decadal/interdecadal scales during the past 500 years. Palaeogeogr Palaeoclimatol Palaeoecol 254:541-549

Yao T, Masson-delmotte V, Gao J, Yu W, Yang X, Risi C, Sturm C, Werner M, Zhao H, He Y, Ren W (2013) A Review of climattic controls on $\mathrm{d} 18 \mathrm{O}$ precipitationover the Tibetan Plateau: observation and simulations. Rev Geophys 51:525-548

Zhou T, Zou L (2010) Understanding the predictability of East Asian summer monsoon from the reproduction of land-sea thermal contrast change in AMIP-type simulation. J Clim 23:6009-6026 